\title{
Поэтика. Контекст
}

Достоевский и мировая культура. Филологический журнал. 2021. № 4 (16). Dostoevsky and World Culture. Philological journal, no. 4 (16), 2021.

Научная статья / Research Article

УДК 821.16.1.0

ББК $83.3(2=411.2)$

https://doi.org/10.22455/2619-0311-2021-4-88-122
This is an open access article distributed under the Creative Commons Attribution 4.0 International (CC BY 4.0)

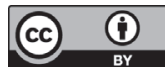

(C) 2021. Татьяна Боборыкина

Санкт-Петербургский Государственный Университет, Санкт-Петербург, Россия

\section{Уже не подросток, еще не князь}

\author{
(C) 2021. Tatiana A. Boborykina
}

St. Petersburg State University, St. Petersburg, Russia

\section{No Longer an Adolescent, Not Yet a Prince}

Информация об авторе: Боборыкина Татьяна Александровна, кандидат филологических наук, доцент, ст. преподаватель Факультета Свободных Искусств и Наук СПбГУ, Санкт-Петербургский Государственный Университет, Университетская набережная, д. 7-9, 199034 Санкт-Петербург, Россия.

https://orcid.org/0000-0002-8661-3435

E-mail: t.boborykina@spbu.ru

Аннотация: В статье делается попытка ответить на некоторые из многочисленных вопросов, встающих перед читателем одного из самых загадочных романов Достоевского - «Подросток». Что означают, рассыпанные по всему тексту аллюзии на Пушкина, Диккенса, Шекспира и так далее? Каков скрытый смысл стилистики романа, его «кинематографической» визуальности? И наконец, какой смысл заложен в названии и почему через весь роман проходит тема «княжеской» фамилии подростка, который при этом - «не князь»? Эти вопросы прослеживаются через путь главного героя. Определяются причины возникновения его идеи «стать Ротшильдом» и проводится параллель с проблемами «Рождественской песни в прозе» Диккенса. Обнаруживается связь повести Диккенса и романа Достоевского с библейской притчей «О богаче и Лазаре». Момент перелома «идеи» подростка сравнивается с рождественским рассказом Достоевского «Мальчик у Христа на елке». Особый интерес представляют приемы «потока сознания», «внутреннего монолога, предвосхищающие открытия модернизма. В фокусе внимания также пластические метафоры, «крупные планы» в которых визуализируются ведущие мотивы произведения. В анализе духовного портрета подростка большая роль отводится не только его «двум отцам», но и школьному товарищу Ламберту, чья полу-мифологическая фигура получает разные толкования. Вся структура статьи приводит к расшифровке лаконичной формулы «Гамлет-христианин», с которой начинаются «Заметки, планы и наброски» к роману. Эта максима трактуется как трансцендентальная 
цель, к которой автор ведет героя с первой строки своих замыслов. В контексте темы «Уже не подросток, еще не князь» - сквозной нитью проходит раскрытие метафорического смысла понятий «подросток» и «князь». Поиск ответов на затронутые вопросы приводит к выводу о том, что метафизическое пространство романа огромно и вмещает в себя не только путь подростка, но и пути развития России и Европы.

Ключевые слова: Достоевский, Пушкин, Диккенс, Шекспир, подросток, визуальная метафора, «князь-Христос», «Рождественская песнь в прозе», «Мальчик у Христа на елке», «Гамлет-христианин».

Для цитирования: Боборыкина Т.А. Уже не подросток, еще не князь // Достоевский и мировая культура. Филологический журнал. 2021. № 4(16). С. 88-122. https:// doi.org/10.22455/2619-0311-2021-4-88-122

Information about the author: Tatiana A. Boborykina, PhD in Philology, Associate Professor, Senior Lecturer, St. Petersburg State University, Universitetskaya Emb. 7-9, 199034 St. Petersburg, Russia.

https://orcid.org/0000-0002-8661-3435

E-mail: t.boborykina@spbu.ru

Abstract The essay explores some of the numerous questions which the readers of The Adolescent - one of the most enigmatic novels by Dostoevsky - face. What is the hidden meaning of the various allusions to Pushkin, Dickens, Shakespeare, which are spread all over the text? What is the encoded meaning of the novel's specific style, its "cinematographic" visuality, and finally - what is the meaning of the very title, and why it is constantly repeated that the adolescent with a "princely" name is not a "Prince"? The path of the hero and his idea of "becoming Rothschild" is traced. The reasons for such an idea are discovered through parallels to A Christmas Carol by Dickens. The Biblical parable about the rich man and Lazarus is defined as the source of both Dickens's story and part of Dostoevsky's novel. The point of transformation of the adolescent's “idea” is compared with Dostoevsky's Christmas story The Beggar Boy at Christ's Christmas Tree. Special attention is paid to such elements of style as the "stream of consciousness", "internal monologue" etc., which foreshadow revelations of modernism. Cinematographic devices like "close-ups" and materialized metaphors are also in the focus of attention, as most of them visualize the leitmotifs of the novel. The analysis of the adolescent's spiritual portrait discovers an important role of not only his "two fathers", but also his school friend Lambert, whose grotesque and almost mythological figure is interpreted in various ways. The structure of the essay leads to the decoding of the laconic formula "Hamlet-Christian" with which Dostoevsky opens his outline and notes to the novel. The maxim is interpreted as some transcendental goal to which the author is leading his hero from the very first line of the novel's plan. In the context of the theme "No longer an adolescent, not yet a Prince" the essay explores the metaphorical content of such notions as "adolescent" and "prince". The research highlights that the metaphysical realm of the novel is enormous and embraces not only the path of its young hero but also the possible ways of the historical development of both Russia and Europe.

Keywords: Dostoevsky, Pushkin, Dickens, Shakespeare, adolescent, visual metaphor, "Prince-Christ", A Christmas Carol, The Beggar Boy at Christ's Christmas Tree, "Hamlet-Christian".

For citation: Boborykina, T.A. "No Longer an Adolescent, Not Yet a Prince”. Dostoevsky and World Culture. Philological journal, no. 4 (16), 2021, pp. 88-122. (In Russ.) https://doi. org/10.22455/2619-0311-2021-4-88-122 
Роман «Подросток» до сих пор остается загадкой. Существует немало работ, исследующих это позднее произведение писателя с разных сторон, и все же, за их пределами встает немало вопросов. Почему Бердяев считал его «одним из самых гениальных и не до конца оцененных творений Достоевского» [Бердяев, 1994а, с. 154]? О чем этот роман? Хорош он или плох? Что означают, рассыпанные по всему тексту аллюзии на Пушкина, Диккенса, Шекспира и так далее? Каков скрытый смысл его пластически-визуальных, «кинематографических» метафор? И, наконец, что такое «подросток» и почему Долгорукий - «просто Долгорукий», не князь?

Действительно, что стоит за словом «Подросток», означающим переходный возраст от детства к юношеству, примерно от 12 до 16 лет? Писатель явно что-то кодирует в лаконичной формуле такого названия, ведь его герой - Аркадий Долгорукий, которому уже 20, формально не является подростком. Он также не является и князем, хотя в романе лейтмотивом звучит тема его княжеской фамилии, с настойчивым рефреном: - Князь? - Не князь. Что зашифровано в аллюзии на князя Долгорукого, который считается одним из самых противоречивых и беспокойных персонажей российской истории? Сын Владимира Мономаха, он начал княжить еще «подростком» и, по мнению ряда историков, носил прозвище «Долгорукий» за «алчность к приобретению». В этом ракурсе «Долгорукий» созвучен идее Аркадия «стать Ротшильдом», при этом подросток болезненно ощущает себя «не князем».

Определяя основную линию своего замысла, Достоевский писал: «Подросток хотя и приезжает с готовой идеей, но вся мысль романа та, что он ищет руководящую нить поведения, добра и зла, чего нет в нашем обществе, этого жаждет он, ищет чутьем, и в этом цель романа» [Достоевский, 1972-1990, т. 16, с. 51]. «Поиск руководящей нити», предполагающий процесс внутреннего роста, духовного взросления, видимо и скрывается в заглавии. И, могу предположить, этот мотив неразрывно связан с темой княжеской фамилии.

Написанный за несколько лет до «Подростка» роман «Идиот» (1868) начинается с того, что князь Мышкин, также как и Аркадий, приезжает в Петербург и приезжает он со своей «готовой идеей», то есть - он с самого начала тот «князь-Христос», как в черновиках к роману называет его Достоевский. Как отметил Мочульский: «Построение “Подростка" аналогично построению “Идиота” <...> [Мочульский, 1995, с. 489]. 
Мышкин именно тот герой, которого и хотел изобразить Достоевский - «положительно прекрасный». Это совершенно бескорыстный, не от мира сего молодой человек, непохожий, например, на Ганю Иволгина, который проповедует философию, сходную с ротшильдовской идеей Аркадия. Обращаясь к Мышкину в страстном монологе, Ганя так формулирует свою идею накопления: «<...> у меня цель капитальная есть. Вы вот думаете, что я семьдесят пять тысяч получу и сейчас же карету куплю. Нет-с, я тогда третьегодний старый сюртук донашивать стану, и все мои клубные знакомства брошу <...> чрез пятнадцать лет скажут: "Вот Иволгин, король иудейский” [Достоевский, 1972-1990, т. 8, с. 105]. В пылу воображения Ганя, можно сказать, «оговаривается по Фрейду». Он, конечно же, имеет в виду Ротшильда, или кого-то вроде него, хотя выражение «царь иудейский» в Новом завете применяется к Иисусу Христу (Мф. 2: 2; 27: 11, 29, 37). Иными словами, на бессознательном уровне, он Христа подменяет символом своей веры - деньгами. В этом смещении или соединении двух противоположных понятий уже как будто заложена идея будущего романа, где в одном человеке происходит нескорый внутренний переход от «подростковой» идеи Ротшильда к более зрелой идее «князя-Христа».

В отличие от князя Мышкина, Аркадий формируется на наших глазах, он действительно ищет ту самую «руководящую нить поведения, добра и зла». Процесс его становления не завершён, поэтому герой - подросток, он ещё должен вырасти во всех смыслах слова. Начав с идей «Гани», от «просто Долгорукого» он медленно, с переменным успехом, с ошибками и провалами, идет в сторону взросления души. Исповедь подростка становится рассказом о пути к себе, к тому, чтобы внутренне стать «князем». Известно, что при создании портрета князя Мышкина в разработках писателя наряду с образом Христа присутствовал и Дон Кихот. Работая над образом Аркадия, Достоевский и его сравнивает с Дон-Кихотом: «Вообще весь роман через лицо Подростка, ищущего правды жизненной (Жиль Блаз, Дон-Кихот)» [Достоевский, 1972-1990, т. 16, с.63].

В «поиске правды» большую роль играет «духовный отец» Аркадия - Макар Иванович Долгорукий. В самом имени «Долгорукий» соединяются противоположные понятия так же, как они соединяются в двусмысленном выражении Гани о «царе иудейском». Не случайно, названный отец подростка, чью фамилию он носит «<...> ужасно любил и уважал свою фамилию Долгорукий <...> ему 
нравилась его фамилия именно потому, что есть князья Долгорукие» [Достоевский, 1972-1990, т. 13, с. 14]. То есть «подросток» - тот, кто проходит стадию роста духовного и «Долгорукий» - тот, кто с одной стороны оправдывает прозвище, данное за «алчность к приобретению», а с другой - несет в себе княжеский благородный дух.

История Аркадия тесно переплетается с одним из героев романа - молодым князем Сокольским, но он князь не в том смысле, в котором Макар Иванович гордился своей фамилией. Князь Сережа говорит, например, о том, что из его положения есть выход княжеский, а есть - лакейский, но, будучи князем по рождению, он сознательно действует «как лакей» [Достоевский, 1972-1990, т. 13, с. 265]. Обратный вектор у подростка, который движется от «лакея» к князю и в подтверждении этому к концу романа его не раз называют «князем». И не зря в романе есть два князя Сокольских - не родственники, а однофамильцы. Понятно, что этот выбор сделан писателем не от недостатка воображения или арсенала имен. Достоевский, вероятно, хочет подчеркнуть, что князья разные, даже однофамильцы, и подросток на пути не просто к какому угодно «князю». Он на пути к раскрытию в себе той сути своей фамилии, которая имеет отношение к высокому, каким бы «маленьким» он ни был в физическом и метафизическом смыслах. В сочетании «князь Мышкин» также угадывается это соотношение. Намек на него, как эхо насмешек над князем тех, кто прозвал его «идиотом», слышится в странном, на первый взгляд, сравнении Аркадия - «смеялась надо мной, как над мышью» [Достоевский, 1972-1990, т. 13, с. 63]. Что-то созвучное прозвищу Мышкина звучит и на простодушную реплику подростка: « - просто Долгорукий» в реакции: «- А, просто! Дурак!» [Достоевский, 1972-1990, т. 13, с. 7].

Когда Аркадий на аукционе свершает первую «пробу» своей ротшильдовской идеи, он покупает никчемную и совершенно ненужную ему вещь, но тут же на улице продает ее в несколько раз дороже человеку, который хочет вернуть ее тем, кому она действительно дорога. Здесь сталкиваются «алчность к приобретению» и благородство, цена и ценность. И Аркадий выбирает для себя цену, что и составляет определенную суть его идеи, потребовавшей от него на практике не высоких, а низких чувств: «Один шаг - и семь рублей девяносто пять копеек нажил! Шаг был бессмысленный, детская игра, я согласен, но он все-таки совпадал с моею мыслью и не мог не взволновать меня чрезвычайно глубоко.... Впрочем, нечего чувства 
описывать. Десятирублевая была в жилетном кармане, я просунул два пальца пощупать - и так и шел, не вынимая руки. Отойдя шагов сто по улице, я вынул ее посмотреть, посмотрел и хотел поцеловать» [Достоевский, 1972-1990, т. 13, с. 39].

Такие чувственные желания в отношении денег вызывают в памяти пушкинского скупого рыцаря, который ждет момента встречи со своими капиталами «как молодой повеса ждет свиданья / C какой-нибудь развратницей лукавой / Иль дурой, им обманутой <...> [Пушкин, 1957-1958, т. 5, с. 342]. Да подросток и сам в рассуждении о своей «идее» признается, что «еще в детстве выучил монолог Скупого рыцаря Пушкина» именно считая, «что выше этого, по идее, Пушкин ничего не производил» [Достоевский, 1972-1990, т. 13, c. 75].

Незамедлительно после ростовщической продажи альбома Аркадий бросается на помощь роскошной даме в дорогом экипаже: «У подъезда дома вдруг прогремела карета; швейцар отворил двери, и из дому вышла садиться в карету дама, пышная, молодая, красивая, богатая, в шелку и бархате, с двухаршинным хвостом. Вдруг хорошенький маленький портфельчик выскочил у ней из руки и упал на землю; она села; лакей нагнулся поднять вещицу, но я быстро подскочил, поднял и вручил даме, приподняв шляпу. <..> Карета загремела. Я поцеловал десятирублевую». [Достоевский, 1972-1990, т. 13, с. 39].

И это именно та «десятирублевая», выторгованная им у человека, который действительно хотел помочь другой даме, вынужденной продать все «с молотка». Бесчувственность Аркадия к утратам тех, на чьем горе он «нажился» навевает еще один мотив «Скупого рыцаря», где барон, наслаждаясь зрелищем своего золота, размышляет: «Кажется, не много, / А скольких человеческих забот, / Обманов, слез, молений и проклятий /Оно тяжеловесный представитель!» [Пушкин, 1957-1958, т. 5, с. 343].

Не случайно, конечно, упомянут шлейф на дорогом платье, или, как презрительно его называет Аркадий - «хвост». Совсем незадолго до аукциона, он скептически рассуждал о неприличии подобного наряда: «Идет по бульвару, а сзади пустит шлейф в полтора аршина и пыль метет; каково идти сзади: или беги обгоняй, или отскакивай в сторону, не то и в нос и в рот она вам пять фунтов песку напихает. К тому же это шелк, она его треплет по камню три версты, из одной только моды, а муж пятьсот рублей в сенате в год 
получает: вот где взятки-то сидят! Я всегда плевался, вслух плевался и бранился!» [Достоевский, 1972-1990, т. 13, с. 25].

На фоне подобной «нигилистической» риторики особенно подобострастно выглядит непроизвольный порыв Аркадия услужить даме в модном наряде. И здесь также есть развитие пушкинской темы - скупой барон видит в деньгах «<...> господ; и сам им служит. / И как же служит? как алжирский раб, /Как пес цепной» [Пушкин 1957, т. 5, с. 338].

Это почти подсознательное «служение» деньгам показано Достоевским посредством визуальной метафоры - через параллельность действий Аркадия и лакея. Сцена с женщиной в экипаже и эпизод с лакеем - наглядное, пластическое воплощение «лакейства» подростка. Он поступил, как «Ротшильд», как «скупой рыцарь», воспользовавшись ситуацией и извлекая выгоду для себя. И это подчеркнуто его поведением после сделки.

Случай с наклоном за портфелем бок о бок с лакеем, ничего не меняет в сюжете, но символически он говорит многое на уровне сверхсюжета, даёт направление в сторону содержания, смысла. Этот эпизод (как и многие другие в романе) по своей природе кинематографичен. В его визуальности есть то единство внешнего и метафорического, которое автор показательного в этом отношении «Портрета Дориана Грея» считал едва ли не важнейшим свойством искусства: “All art is at once surface and symbol” («Всякое искусство одновременно есть и поверхность, и символ» [Уайльд, 1912, т. 2, c. 4]). Жаль, что этот момент в романе прошел мимо внимания постановщика фильма (вернее - телевизионного сериала), снятого по роману в 1983 году. В тоже время, сам текст Достоевского производит впечатление настоящего художественного кино, опирающегося не столько на вербальный, сколько на иной, образный, пластически-визуальный язык. Сцена, которая происходит в долю секунды, могла бы быть снята рапидом (что выглядит на экране, как «замедленное действие»), и такой пристальный взгляд на это событие подчеркнул бы почти хореографическую синхронность пластики подростка и лакея. Ведь за видимым движением тела встает невидимое «движение души», в данном случае, подчеркнуто лакейское, низкое. Не случайно и то, что это движение поклона, опускание корпуса вниз - этот пластический момент насквозь метафоричен. Как отмечал Николай Бердяев, у Достоевского «все внешнее $-<. .>$ лишь знаки, символы внутреннего, духовного человеческого мира, 
лишь отображения внутренней человеческой судьбы» [Бердяев, 1994, т. 2, с. 27].

У Достоевского есть такое замечание: «Известно, что целые рассуждения проходят иногда в наших головах мгновенно, в виде каких-то ощущений, без перевода на человеческий язык <...> [Достоевский, 1972-1990, т. 5, с. 12]. Эта мысль созвучна идее философа и психоаналитика Эриха Фромма: «Перед вами предстала всего лишь картина, и вы наблюдали ее менее секунды. И все же эта картина гораздо живее и точнее передает ваше состояние, чем рассказ о нем». [Фромм, 2009, с. 19]. Можно сказать, что «целые рассуждения» о лакейском отношении к деньгам подростка показаны со всей очевидностью в мгновенной пластической картине.

Тема «лакейства» как концепция угоднического раболепия появляется в творчестве Достоевского до «Подростка» и развивается после. Еще в «Бесах» (1871-1872) Шатов говорит: «От лакейства мысли все это <...>. Наш русский либерал, прежде всего лакей и только и смотрит, как бы кому-нибудь сапоги вычистить» [Достоевский, 1972-1990, т. 10, с. 110-111]. Примечательно и то, что аллегорическое «сапоги вычистить» в «Подростке» трансформируется в реализованную, овеществленную метафору. Аркадий буквально чистит сапоги своему сомнительному товарищу по школе, а позже сам говорит о лакействе и сапогах в переносном смысле: «<...> ведь действительно я настолько лакей, что никак не могу удовлетвориться тем, что Версилов не отдал меня в сапожники <...> [Достоевский, 1972-1990, т. 13, с. 100]. Само слово «лакей», как и появление лакеев в их буквальном физическом и иносказательных смыслах, но всегда с подтекстом, проходит, если не «красной», то некоей связующей нитью сквозь весь роман.

Уже после «Подростка», в романе «Братья Карамазовы» (1879-1880) Иван, который подобно Аркадию, не уверен в выборе пути и, «порвав вдруг со всем, что его сюда привлекло, готовился вновь повернуть круто в сторону и вступить на новый, совершенно неведомый путь», так размышляет о лакее Смердякове: «<..> Иван Федорович с первого взгляда на него понял, что и в душе его сидел лакей Смердяков, и что именно этого-то человека и не может вынести его душа», - и для себя определяет природу этого лакейства, как «самолюбие необъятное и при том, самолюбие оскорбленное» [Достоевский, 1972-1990, т. 14, с. 242-243]. Этот самоанализ Ивана Карамазова можно отнести и к Аркадию, ведь именно «оскор- 
бленное самолюбие» поначалу движет его замыслами, эмоциями и поступками.

Роман «Подросток» - как сама человеческая мысль - движется в почти модернистском «потоке сознания», смешиваясь с ощущениями, воспоминаниями, ассоциациями, образуя траекторию спирали от настоящего в прошлое, опять к настоящему и так далее, как бы предвосхищая формулу «поисков утраченного времени» Пруста. Вскоре после аукциона и короткой мизансцены с лакеем, в сознании Аркадия всплывает прошлое времен его учебы у Тушара, и тут слово «лакей» возникает вновь, но теперь оно звучит уже напрямую в его адрес, когда учитель при всех кричит: «Ты все равно, что лакей» [Достоевский, 1972-1990, т. 13, с. 97]. Однако, желая избавиться от этого унизительного клейма, он избирает путь, в самом начале которого, как мы уже видели, он становится «лакеем» не по своему незаконному рождению, а по образу мыслей, по душе. Аркадий хотел с помощью денег, с помощью идеи, которая в детстве «утешала его в позоре» [Достоевский, 1972-1990, т. 13, с. 79] обрести власть, но оказалось, что деньги обретают власть над ним. Уже после «пробы» на аукционе в компании молодых людей он говорит о благородстве, задаваясь риторическим вопросом - а нужно ли оно? «Зачем непременно нужно быть благородным?» [Достоевский, 1972-1990, т. 13, c. 49]. Это, по сути, внутренний ход мыслей Аркадия, быть может, какие-то его сомнения относительно правильности своих поступков и идей. Озвучив дилемму о благородстве, он опять слышит в ответ на свою фамилию: «Князь Долгорукий?». И эта тема раскачивается, как маятник, набирая все большую амплитуду, становясь все более драматичной, метафорической и глубокой. В словах о благородстве слышатся первые ноты того мотива романа, который можно назвать «гамлетовским», угадывается созвучие «проклятым вопросам» известного монолога: "Whether "tis nobler in the mind to suffer / The slings and arrows of outrageous fortune...” («Что благородней духом покорятся пращам и стрелам яростной судьбы,/ Иль, ополчась на море смут, сразить их / Противоборством?» [Шекспир, 1960, т. 6, c. 70]). Здесь обозначается перспектива выбора пути в зависимости от того - «что благородней». Таков вопрос. И в такой его постановке будет определяться императив поведения подростка по мере его «роста». Значительно позже, когда сам Аркадий окажется перед экзистенциальным выбором, он сформулирует свою безумную, отчаянную мысль почти словами Гамлета: «<..> покориться, стать 
лакеем <...>, а там уж и убить себя» [Достоевский, 1972-1990, т. 13, c. 269].

Где-то в самом начале романа звучит другой, пожалуй, слишком прямолинейный вопрос: «Где живет Бог»? [Достоевский, 1972-1990, т. 13, с. 31]. Задавший его сам заранее отметает мысль о какой-то разлитой в душе субстанции, но все же ясно, что вопрос о душе. Вслед за вопросом о местожительстве Бога следует другой - о том, где учился Аркадий. В своем ответе: «в Москве-с» он добавляет это «с», считавшееся признаком почтения, но как скажет в «Карамазовых» Снегирев: «Слово-ер-с приобретается в унижении» - и это также продолжает «лакейский» мотив в сложной симфонии формирования личности Аркадия. В его душе пока еще Бог не живет, в ней все еще живет «лакей».

В «набросках» к роману Достоевский писал: «Я бы назвал его подростком, если б не минуло ему 19-ти лет. В самом деле, растут ли после 19 лет? Если не физически, так нравственно» [Достоевский, 1972-1990, т. 16, с. 77]. И подросток растет, он проходит путь своего «нравственного роста», путь в сторону «благородства», но это путь не по прямой из пункта А в пункт В. Подобно Раскольникову, Аркадий то спускается, то идет вверх по метафизической «винтовой лестнице», он как бы ходит «кругами», и это согласуется с трактовкой имени его другого, телесного отца, которую предлагает Т.А. Касаткина: «<..> фамилия Версилов заключает в себе идею вращения, поворота, некого беспорядка: verso (are) (лат.) - катить, катать» [Касаткина, 2004б, с. 197]. Если при этом вспомнить, что Версилов и сам называет себя «вертун», и, кроме того, постоянно сам движется по кругу, то это явно намекает на ту, в принципе, характерную для Достоевского дантовскую, винтообразную структуру трансцендентального пути.

На этом своем спиральном движении Аркадий видит сон. Это эпизод, когда его, как и Голядкина в «Двойнике», с позором изгоняют из общества, причем как раз из-за денег, и это становится «толчком» к самоанализу - как-то пророчески буквально предвосхищающему психоанализ Фрейда - через сон, через воспоминания детства. От страшного унижения и оскорбительного подозрения в воровстве, не видя иного выхода, он решает хоть что-нибудь поджечь. И это можно трактовать, как овеществление метафоры «сжигать мосты», в данном случае иносказательно - «мосты» между ним и рулеткой, связь между ним и деньгами, которую он бессознательно хочет порвать - примерно так, как в романе «Идиот» Настасья Филип- 
повна бросает деньги в огонь. Или можно сравнить это с Версиловым, разбивающим образ, завещанный ему Макаром - «<..> это была аллегория, <...> ему непременно хотелось с чем-то покончить» [Достоевский, 1972-1990, т. 13, с. 410]. Аркадию также хочется с чем-то покончить, чего не высказать словами. Желание устроить пожар еще и метафора внутреннего ожога и желания выплеснуть наружу то, что жгло его изнутри. В состоянии легкого безумия он забирается на забор, над которым возвышаются дрова, чтобы поджечь их, но поднявшись, он «вдруг оборвался и навзничь полетел вниз» [Достоевский, 1972-1990, т. 13, с. 269]. Нельзя не заметить и здесь пластически-визуальный намек. Иначе, зачем Достоевскому эти подробности? Совершенно очевидно, что за физическими действиями встает метафизика смыслов - символика какого-то падения Аркадия, того, что его путь наверх не состоялся. Наполеоновские планы рухнули и это падение - его «Пиковая дама», проигрыш его «мечты», его «идеи». При том, что он выиграл деньги, он сделал по жизни неверный ход.

Когда пушкинский Германн теряет все, Чекалинский «ласково» говорит ему: «Дама ваша убита» [Пушкин, 1957-1958, т. 6, с. 355], и понятно, что в глубоком подтексте, речь не только о «даме пик». Как мы помним, на совести Аркадия тоже есть - ради денег - «убитая дама» - та, обедневшая, вынужденная продать последнее на аукционе. Аркадий падает от того, что «оборвался», что созвучно случившемуся с Германом - «обдернулся» - который так наказан за смерть старой дамы, за свой неверно выбранный путь.

Упав, Аркадий оказывается на дворе среди снега и тех самых брёвен. И вдруг - как будет записано им позже - «ощутил нестерпимый холод, и еще плохо осознавая, что делаю, пополз в угол ворот и там присел, съежившись и скорчившись, в углублении между воротами и выступом стены. Мысли мои мешались, и, вероятно, я очень быстро задремал. Как сквозь сон теперь вспоминаю, что вдруг раздался в ушах моих густой, тяжелый колокольный звон, и я с наслаждением стал к нему прислушиваться» [Достоевский, 1972-1990, т. 13, с. 269-270]. И он узнает в «приятном и плавном» звоне колокол старинной московской церкви, памятный ему с детства. В этом эпизоде намечается метафизический переход Аркадия от идеи денег к Богу. И хоть «церковь не в бревнах, а в ребрах» [Даль, 2007, с. 376], здесь он внутренне уже движется к какому-то Храму, для которого нужны «бревна», у которых он и задремал. И, если аукцион, по его 
словам - «первое бревно того корабля, на котором Колумб поехал открывать Америку» [Достоевский, 1972-1990, т. 13, с. 36], то здесь, на дровяном дворе уже «бревна» другие, и они символически направляют его в иную сторону. Не случайно, во сне Аркадию видится церковь, знакомая с детства.

Подростка часто называют «мальчиком» в черновиках и в романе, и даже сам он о себе говорит: «<...> вот едет маленький мальчик, отставной гимназист, подросток <...> [Достоевский, 1972-1990, т. 13, с. 16]. И это слово, также как и «подросток», относится не к возрасту, а к тому, что является частью внутреннего мира Аркадия. И он - в эпизоде у бревен - засыпает, как тот ребенок, которому у таких же дров, во дворе на снегу является Бог в рассказе 1976 года - «Мальчик у Христа на елке». В рождественской истории маленький мальчик «вдруг забежал сам не знает куда, в подворотню, на чужой двор, - и присел за дровами <...> Присел он и скорчился, а сам отдышаться не может от страху и вдруг, совсем вдруг, стало так ему хорошо: ручки и ножки вдруг перестали болеть и стало так тепло, так тепло, как на печке; вот он весь вздрогнул: ах, да ведь он было заснул! Как хорошо тут заснуть. <..> - Пойдем ко мне на елку, мальчик, - прошептал над ним вдруг тихий голос. Он подумал было, что это всё его мама, но нет, не она; кто же это его позвал, он не видит, но кто-то нагнулся над ним и обнял его в темноте, а он протянул ему руку и... и вдруг, - о, какой свет!» [Достоевский, 1972-1990, т. 22, с. 16].

Эти строки из «Дневника писателя» звучат, как отзвук на ту часть романа, когда Аркадий засыпает во дворе на снегу. Более того, ребенок, встретивший в своем предсмертном сне Христа, как будто с самого начала нечаянно забрел из еще ненаписанного рассказа на первые страницы «Подростка». Среди угрюмых прохожих вечернего Петербурга Аркадию встречается мальчик «такой маленький, что странно, как он мог в такой час очутиться один на улице; он, кажется, потерял дорогу; одна баба остановилась было на минуту его выслушать, но ничего не поняла, развела руками и пошла дальше, оставив его одного в темноте. Я подошел было, но он с чего-то вдруг меня испугался и побежал дальше» [Достоевский, 1972-1990, т. 13, с. 64]. Этот появившийся на миг ниоткуда и исчезнувший в никуда образ, так же как и случай с лакеем - никак не связанные с сюжетом немые сцены, уличные зарисовки. Однако, как говорит Версилов Аркадию: «Не забывай мелочей, главное - не забывай 
мелочей, чем мельче черта, тем иногда она важнее» [Достоевский, 1972-1990, т. 13, с. 223]. И действительно, при всей внешней случайности в этих «мелочах» кодируются мотивы и лейтмотивы романа. Потерявшийся мальчик - это сам Аркадий на перепутьях своих жизненных ориентиров. «Не нуждается в доказательствах то, что система персонажей Достоевского сориентирована по оси “святость / грешность” с Христом в качестве положительной точки отсчета, а “ребенок” (“дитя”) тесно связан с положительным этическим идеалом». [Баршт, 2003, с. 9]. С «положительным этическим идеалом» может быть связано и возвращение в детство, например, через воспоминания. У Диккенса или у Фрейда - это своего рода способ вернуться к еще нетронутой коррозией душе, способ ее излечения. В этом отношении Рождественский рассказ Достоевского (так же как и эпизод у дровяного склада в романе), можно назвать совершенно диккенсовским, в частности, отражающим многие мотивы «Рождественских повестей» английского писателя.

Как и в повестях Диккенса, в романе Достоевского у Аркадия происходит момент соприкосновения со своей душой через пробуждение памяти звоном церковного колокола: «густой, тяжелый колокольный звон, и я с наслаждением стал к нему прислушиваться. <...> Колокол ударял твердо и определенно по одному разу в две или даже в три секунды, но это был не набат, а какой-то приятный, плавный звон, и я вдруг различил, что это ведь - звон знакомый, что звонят у Николы, в красной церкви напротив Тушара <...> [Достоевский, 1972-1990, т. 13, с. 270]. Колокол, как музыкальный рефрен звонит, причем по-разному, на протяжении всего сна. Так же, как у Диккенса звонят колокольчики и колокола в истории о Скрудже, и постоянно и по-разному раздается колокольный звон в другом рождественском рассказе «Колокола» (The Chimes, 1844), где происходит духовное пробуждение героя.

В статье о «Мальчике у Христа на елке» Т.А. Касаткина обращает наше внимание на то, что все внешние физические явления рассказа обладают бесконечной метафизической глубиной: «Достоевский строит образ в своем повествовании так, что сквозь тонкую (хотя и вполне плотную) оболочку героев и событий их жизни, сквозь существующее, сиюминутное читателю являются вечные лики и вечное бытие, человек оказывается каждое мгновение (которое есть не что иное, как вход в вечность) не сосредоточенным в этом мгновении, на поверхности бытия, но распахнутым, размахнувшимся на 
всю метафизическую глубину, от ада до рая». [Касаткина, 2019а, c. 18]. Это важнейший принцип в понимании самой фактуры текста Достоевского, и его в полной мере можно отнести к интересующему нас роману. Сновидение Аркадия у бревен создает ощущение переломного момента его духовной жизни. Это всплывающая из глубин памяти «внутренность души» [Достоевский, 1972-1990, т. 13, с. 5], о которой он говорит с самых первых страниц своих записей и которую он почти позабыл в погоне за своей «идеей».

Давно стало общим местом сравнение рождественского рассказа Достоевского «Мальчик у Христа на елке» и «Рождественской песни в прозе» Диккенса. Мне и самой приходилось писать об этом еще в 1996 году в книге о Диккенсе ${ }^{1}$. Однако, только сейчас стало понятно, что оба эти произведения имеют отношение к «Подростку». И, если вообще говорить о мотивах Диккенса в романе - это не только «Лавка древностей», «Большие надежды» и «Давид Копперфильд», о чем уже не раз писали². Как тонко подмечает в своем объемном труде «Мантия пророка» американский исследователь Джозеф Фрэнк, у самого Достоевского есть переход к стилистике Диккенса, особенно в части Заключения, начинающейся словами: «Теперь, когда я пишу эти строки, - на дворе весна, половина мая, день прелестный, и у нас отворены окна. Мама сидит около него; он гладит ей щеки и волосы и с умилением засматривает ей в глаза» [Достоевский, 1972-1990, т. 13, с. 446], и с его характеристикой тональности всего этого пассажа нельзя не согласиться: “These speculations form part of the epilogue, which has a distinctly Dickensian tonality" [Frank, 2002, p. 193].

Как известно, «Лавка древностей» напрямую упоминается в романе, когда Тришатов дает свой вольный пересказ сюжета и впечатления о нем: «Ах, Долгорукий, читали вы Диккенса “Лавку древностей”? <...> там одно место в конце, когда <...> старик и <...> внучка его, <...> приютились наконец где-то на краю Англии, близ какого-то готического средневекового собора, <...> и вот раз закатывается солнце, и этот ребенок на паперти собора, вся облитая последними лучами, стоит и смотрит на закат с тихим задумчивым созерцанием в детской душе, удивленной душе, как будто перед какой-то загадкой, потому что и то, и другое, ведь как загадка - солнце, как мысль Божия, а собор, как мысль человеческая... не правда ли?»

1 См.: [Боборыкина, 1998].

2 См.: [Криницын, 2010; Бабук, 2012]. 
[Достоевский, 1972-1990, т. 13, с. 353]. Возможно, здесь через Диккенса, который, как представляется, внутренне становится неотъемлемой частью пространства романа, намечена одна из сквозных тем «Подростка» - удивление перед загадкой человеческой души и стремление постичь «мысль человеческую» и «мысль Божию». Эта тема звучит ранее в словах Макара Долгорукого: «Трудно человеку знать про всякий грех, что грешно, а что нет: тайна тут, превосходящая ум человеческий. <...> Тайна что? Все есть тайна, <...> во всем тайна Божия» [Достоевский, 1972-1990, т. 13, с. 287].

В диалоге Аркадия и Макара есть деталь, как бы предвосхищающая цитату из Диккенса и созвучная ей: «Вы все говорите про “тайну”; что такое “восполнивши тайну свою”? - спросил я и оглянулся на дверь. Я рад был, что мы одни и что кругом стояла невозмутимая тишина. Солнце ярко светило в окно перед закатом» [Достоевский, $1972-1990$, т. 13, с. 287]. Солнце и раньше возникало в романе, как метафора света и надежды - при встрече с Крафтом, где Аркадий говорит о совести и пытается докопаться до «правды». Его новый товарищ, который проповедует «скрепляющую идею», заботу о будущем России, представляется ему тем самым светом: «Я вас ждал, как солнца, которое все у меня осветит» [Достоевский, 1972-1990, т. 13, с. 56]. Но к концу встречи, когда диалог с Крафтом приобретает все большую метафоричность, на вопрос какой час во дню он больше всего любит, Аркадий отвечает: «Час? Не знаю. Я закат не люблю» [Достоевский, 1972-1990, т. 13, с. 61].

В этом романе-исповеди, романе-самоанализе, в этом «потоке сознания», Аркадий сам задается вопросом: «почему Крафт удивился, что я не люблю заката?» [Достоевский, 1972-1990, т. 13, c. 62] и мысль об этом наводит его на новые нежные размышления о матери и упреков к самому себе, раскаяние за грубое поведение с ней. Позже, услышав о том, что Крафт застрелился, Аркадий догадывается - «на закате солнца» [Достоевский, 1972-1990, т. 13, c. 128]. Закат солнца - это все время о чем-то еще, о чем-то большем и в самом общем смысле о том, что имеет отношение к душе. Поначалу Аркадия раздражает вид закатных лучей в его комнате: «<...> я знал, что в четвертом часу, когда солнце будет закатываться, то косой красный луч его ударит прямо в угол моей стены и ярким пятном осветит это место <...> то, что я знал об этом вперед, как дважды два, разозлило меня до злобы» [Достоевский, 1972-1990, т. 13, с. 283]. Но эта злоба прерывается обращением к Богу, которое 
он слышит непонятно откуда - только звук голоса, только слова, произнесенные полушепотом: «Господи, Иисусе Христе, Боже наш, помилуй нас» [Достоевский, 1972-1990, т. 13, с. 283-284]. Этот момент глубоко символичен. Может быть, он является косвенным ответом на вопрос о том «где живет Бог»? Тот, кто произносит эти слова - «отец» Аркадия, которого он раньше не видел. Но вот уже слышен голос, он все ближе... Оказывается, он живет совсем рядом... Вспоминая свою первую встречу с тем, кто не является его физическим отцом, но кто по-отечески его любит, Аркадий запишет свои ощущения, где то же закатное солнце уже видится ему совсем иначе: «Я лежал лицом к стене и вдруг в углу увидел яркое, светлое пятно заходящего солнца <...> и вот, помню, вся душа моя как бы взыграла и как бы новый свет проник в мое сердце. Помню эту сладкую минуту и не хочу забыть. Это был лишь миг новой надежды и новой силы...» [Достоевский, 1972-1990, т. 13, с. 291].

Закат солнца меняет свое содержание, часто становясь чем-то вроде отражения внутреннего состояния героя (как описание меняющейся луны, в зависимости от того, кто на нее смотрит в «Саломее» Уайльда) - от злобы, разочарования, раздражения к ощущению «надежды и новой силы». И поразительно, как один и тот же закат, с разницей в короткое время духовной беседы Аркадия с Долгоруким, видится ему в «другом свете», в свете какой-то новой Божественной красоты.

Как отмечает Т.А. Касаткина: «После разговора с Макаром, который посвящен смерти во Христе, и надежде новой жизни, и тому, что “и по смерти любовь”, заходящее солнце становится в сердце Аркадия символом Христа - Солнце правды, умирающего, чтобы воскреснуть, гаснущего затем, чтоб из гроба воссиял свет и просветил всю земную мглу, “преисподняя земли”, чтобы во всем, во всякой вещи, торжествовало “благообразие” [Касаткина, 2003, с. 61].

Настойчивый лейтмотив заката проходит через разные этапы пути подростка. Почти по Диккенсу - «мысль Божия» как бы воплощается в самих закатных лучах и в словах «духовного отца» Аркадия, скитальца по монастырям и скитам России. «Мысль человеческая» воплотится в рассказе его «земного» отца о скитаниях по Европе, где также возникнет образ косых лучей заходящего солнца. Но для Версилова это не «свет новой надежды», а «заходящее солнце последнего дня европейского человечества» [Достоевский, 1972-1990, т.13, с. 375]. Метафорически амплитуда смыслов закатного света 
отражает скитания души подростка, скитания его мыслей как бы между «идеями» своих «двух отцов» - Долгорукого и Версилова, между идеями человеческой и божественной.

Помимо столь важного концепта заходящего солнца - характерного и для других произведений Достоевского, а здесь напрямую рифмующегося с Диккенсом - есть в романе и другие связи с английским писателем.

Если говорить о мотиве влияния денег на душу человека, то кроме других произведений Диккенса, «Подросток» в большой степени соотносится с романом «Большие надежды» (Great Expectations, 1861). В Аркадии можно увидеть сходство с сиротой Пипом - когда он, так же как и его английский предшественник, проявляет постыдное «фанфаронство». Трансформация обоих героев и их тяга к внешнему и какому-то по-мольеровски мещанскому выражению богатства, связаны с неожиданным обретением средств и их влиянием на образ мыслей этих духовно незрелых подростков. В подтексте темы приобретения обоими героями дорогой одежды угадывается намек на «дорогие одежды», которые носил богатый человек из притчи o «Богаче и Лазаре», о которой позже пойдет речь. Но в отношении собственно денег еще большую связь «Подростка» можно уловить с повестью «Рождественская песнь в прозе» (A Christmas Carol. In Prose, 1843) и романом «Домби и сын» (Dombey and Son, 1846) произведениями, в которых вскрывается обратно пропорциональная зависимость между состоянием материальным и состоянием души.

При этом у Достоевского, как и у Диккенса, деньги не сами по себе плохи. Все зависит от того, чему они служат и от того, чем сам человек платит за обладание ими. Как правило, плата - сам человек, его внутренний мир. Проблема разных взаимоотношений денег и человека хорошо видна в романе «Идиот», где - опять же, пластически-визуально - в сцене упомянутой выше, когда Настасья Филипповна бросает деньги в камин, Ганя делает унизительную попытку броситься за ними. А князь Мышкин, который впоследствии станет обладателем больших денег, ничуть не исказивших его душу, поражен движением души Настасьи Филипповны. У Диккенса внутренняя связь денег и человека рельефно показана в романе «Домби и сын» и особенно - в «Рождественской песне» - и там, и там налицо смертельный холод души. Для их главных героев

3 Подробнее об этом: [Касаткина, 2004а; Тарасова, 2012; Гажева, 2018]. 
деньги - мера всех вещей, ведь только они «могут все или почти все». В известной степени это согласуется с идеей подростка: «<..> деньги - это единственный путь, который приводит на первое место даже ничтожество» [Достоевский, 1972-1990, т.13, с. 74].

Подобно герою рождественской повести Диккенса, который ничуть не тяготится одиночеством и оправдывает свой отказ в благотворительности тем, что оплачивает остроги и работные дома: «Я хочу, чтобы меня оставили в покое <..> я не имею средств баловать бездельников. Я поддерживаю упомянутые учреждения, и это обходится мне недешево. Желающие могут обращаться туда» [Диккенс, 1959, т. 12, с. 14], подросток заявляет: «Пока у меня есть два рубля, я хочу жить один, ни от кого не зависеть $<. . .>$ Я никому ничего не должен, я плачу обществу деньги в виде фискальных поборов <...> а больше никто ничего с меня требовать не смеет» [Достоевский, $1972-1990$, т. 13, с. 48]. Интересно, что словом, как будто сошедшим со страниц «Рождественской повести» определяет Достоевский идею подростка: «Нажива его идея» [Достоевский, 1972-1990, т. 16, с. 80]. Тоже говорит и о Скрудже, отвергнутая им девушка: "Another idol has displaced me $<\ldots>$ a golden one <...> You weigh everything by Gain” [Dickens, 1984, p.73] («Разве не видела я, как все твои благородные стремления гибли одно за другим и новая всепоглощающая страсть, страсть к наживе, мало-помалу завладела тобой целиком!» [Диккенс, 1959, т.12, с. 43]).

Очевидно, что страсть к накопительству и у Скруджа, и у Аркадия связана с тем, что им обоим чего-то важного не хватало в детстве. Одновременно этот мотив у обоих писателей связан и с идеей возможного перерождения героя, его духовного прозрения - через возвращение в воспоминаниях и снах в свое детство, к точке отсчета внутренних изменений.

Аркадий опровергнет напрашивающиеся причины возникновения своих планов разбогатеть: «Нет, не незаконнорожденность, которою так дразнили меня у Тушара, не детские грустные годы, не месть и не право протеста явились началом моей “идеи” [Достоевский, 1972-1990, т. 13, с. 72]. Однако сам Достоевский утверждает: «Подросток потому, имея отца, начал копить и возмечтал о Ротшильде, что он (отец) давным-давно относится к нему более чем небрежно, и молодой человек это давным-давно сознал» [Достоевский, 1972-1990, т. 16, с. 44]. Как замечает Т.А. Касаткина: «В мире, где разорваны все связи и отношения, где человек - экзистенциально 
и онтологически безотцовщина, деньги - единственное, что обеспечивает действительное могущество и защищенность, что дает первое место» [Касаткина 2004б, с. 186].

Джозеф Фрэнк подчеркивает, что мечта о накоплении, ротшильдовом богатстве, дающая подростку осознание власти, не что иное, как компенсаторная функция бедного, терпящего унижения заброшенного ребенка, о котором некому позаботиться: “These self-glorifying intentions $<\ldots>$ are nothing but the pitiful, compensatory daydreams of a poor, neglected schoolboy left to fend for himself emotionally and constantly humiliated..." [Frank, 2002, p. 175].

Как дает понять Диккенс, героя его «Рождественской песни» повело в накопительство примерно то же: Эбенезер Скрудж был заброшенным ребенком, который на каникулах, когда всех детей забирали домой, оставался один в школе в окружении заледенелых глобусов - небесного и земного. Эти, прихваченные изморозью сферы (“<..> the celestial and terrestrial globes <...> were waxy with cold” [Dickens. 1984, p.65]) - овеществленные метафоры холодного отчужденного мира, в котором из травмированного мальчика мог вырасти законченный Скрудж. Что-то похожее на образ, покрытых льдом глобусов, слышится и в словах подростка: «<..> когда Земля обратится в свою очередь в ледяной камень и будет летать в безвоздушном пространстве с бесконечным множеством таких же ледяных камней <...> [Достоевский, 1972-1990, т. 13, с. 49].

В произведении Диккенса «замороженный» скряга (чье имя Эбенизер, кстати, означает «камень») «оттаивает» и кардинально меняет свою философию под воздействием путешествия в детство, под воздействием видений, показанных ему духами Рождества Христова.

И здесь нельзя не вспомнить первое произведение Достоевского - «Бедные люди», где, во-первых, на периферии сюжета о студенте Покровском уже маячат два отца - телесный и духовный. А во-вторых, в контексте Диккенса нам интересен эпиграф к этому роману - цитата из князя Одоевского, о чем Т.А. Касаткина замечает: «Эпиграф к первому произведению Ф.М. Достоевского, взятый из рассказа В.Ф. Одоевского “Живой мертвец”, не так связан с самими “Бедными людьми”, как с творчеством Достоевского в целом» [Касаткина, 2019б, с. 345]. Эпиграф начинается словами: «Ох уж эти мне сказочники!». Можно предположить, что это намек на «сказочника» Диккенса, поскольку весь сюжет рассказа Одоевского 
«Живой мертвец» (1844) во многом воспроизводит ведущий мотив изданной за год до этого «Рождественской песни в прозе» Диккенса. А оба произведения, в свою очередь, уходят корнями в библейскую притчу «О богаче и Лазаре».

Суть этой притчи (Лк. 16:19-31), в том, что был некий богатый человек, наслаждавшийся роскошной жизнью, и также был некий «нищий, именем Лазарь», вечно страдавший от своей бедности и болезней. Когда оба они умерли, то нищий отнесён был Ангелами в место упокоения душ праведников, а богач - в ад, где теперь страдать пришлось ему. И богач взмолился, чтобы Лазарь, которому он в свое время ничем не помог, облегчил его страдания. Но богачу было отказано в этом. И тогда сказал он: «<...> прошу тебя, Отче, пошли его в дом отца моего, ибо у меня пять братьев; пусть он засвидетельствует им, чтобы и они не пришли в это место мучения. <...> если кто из мертвых придёт к ним, покаются» (Лк. 16: 27, 30).

Как мы помним, к Скруджу приходит дух его покойного компаньона Марли, весь опутанный цепями и замками от сундуков с деньгами, чтобы предупредить о наказании, которое ждет его бывшего единомышленника за скупость и жадность, за бесчувствие к беднякам. Герою рассказа Одоевского - богачу и скряге - представляется, что он умер и так же, как Скрудж, он видит близких людей, которые ничуть не жалеют о его смерти и именно потому, что он был страшно скаредным, бесчувственным и жадным. Тут он начинает понимать, что жил неправильно, но «в жизни, что бы ни сделал, все еще можно поправить; перешагнул через этот порог - и все прошедшее невозвратно! Как такая простая мысль в продолжение моей жизни не приходила мне в голову? <...> Ax, если б я знал это прежде!..» [Одоевский, 1959]. Эта фабула явно перекликается с историей перерождения диккенсовского Скруджа и, действительно, нельзя не заметить, что первоисточник восходит к Библии.

Здесь можно вспомнить, что Оскар Уайльд ошибочно назвал притчу «О богаче и Лазаре» (The Rich Man and Lazarus), перепутав ее с притчей о другом, воскресшем Лазаре, когда писал о «Преступлении и наказании»: «<...> убийца и проститутка сходятся вместе и читают притчу о Лазаре и богаче, и <...> отверженная обществом девушка приводит грешника к покаянию» [Уайльд, 1993, т. 2, с. 151]. Однако, при формальной ошибке, «Уайльд не ушел далеко от оригинала, так как и в притче “О Лазаре и богаче” можно найти те опорные, клю- 
чевые слова, которыми обозначен путь Раскольникова к покаянию, подъему и воскресению души» [Боборыкина, 2016, с. 166].

И вряд ли будет ошибкой говорить о том, что в подтексте нравственных исканий Аркадия - от Ротшильда к Христу - и в самом деле угадывается притча о «Богаче и Лазаре». Ведь и там, как и в притче о воскрешении Лазаря - речь о способности к перемене, к раскаянию, и тем самым к воскрешению. От истории о скупости и бесчувственности богача из притчи тянется нить к повести Диккенса, к рассказу Одоевского и к роману Достоевского «Подросток», герой которого постепенно переходит от безнравственности «богача» к переоценкам и перемене в своей душе.

Важная подробность: и в рождественском рассказе Достоевского, и в его романе ребенок теряет монетки - подросток, принесенные матерью и завернутые в платок, мальчик - данные ему доброй женщиной. У Аркадия эти деньги отнимает Ламберт, но Аркадий сохранил платок «с ясно отпечатавшимся кругленьким оттиском монетки» [Достоевский, 1972-1990, т. 13, с. 273]. И эта деталь - оттиск монет на платочке - еще один кинематографический «крупный план», еще одна визуальная метафора:

«Прошли целые полгода, и наступил уже ветреный и ненастный октябрь. Я про маму совсем забыл. О, тогда ненависть, глухая ненависть ко всему уже проникла в мое сердце, совсем напитала его; я хоть и обчищал щеткой Тушара по-прежнему, но уже ненавидел его изо всех сил и каждый день все больше и больше. И вот тогда, как-то раз в грустные вечерние сумерки, стал я однажды перебирать для чего-то в моем ящике и вдруг, в уголку, увидал синенький батистовый платочек ее; он так и лежал с тех нор, как я его тогда сунул. Я вынул его и осмотрел даже с некоторым любопытством; кончик платка сохранял еще вполне след бывшего узелка и даже ясно отпечатавшийся кругленький оттиск монетки; я, впрочем, положил платок на место и задвинул ящик. Это было под праздник, и загудел колокол ко всенощной <...> я завернулся с головой в одеяло и из-под подушки вытянул синенький платочек: я для чего-то опять сходил, час тому назад, за ним в ящик и, только что постлали наши постели, сунул его под подушку. Я тотчас прижал его к моему лицу и вдруг стал его целовать. “Мама, мама”, - шептал я, вспоминая, и всю грудь мою сжимало, как в тисках. Я закрывал глаза и видел ее лицо с дрожащими губами, когда она крестилась на церковь, крестила потом меня, а я говорил ей: “Стыдно, смотрят”. “Мамочка, мама, раз-то 
в жизни была ты у меня... Мамочка, где ты теперь, гостья ты моя далекая? Помнишь ли ты теперь своего бедного мальчика, к которому приходила...» [Достоевский, 1972-1990, т. 13, с. 273].

Эта картина воспоминания с глубинным по своему содержанию «крупным планом» - не монет, не платочка, а лишь оттиска на нем - не вещественное, но чувственное и даже зримое присутствие чего-то незримого. И метафора этого момента прозрачна: не деньги ценны, а любовь. Все это приходит к Аркадию (как и к герою Диккенса Скруджу) во сне, но от этого «воскрешающего» сна его будит Ламберт - тот, чьим «лакеем» он был в гимназии, с кого там снимал сапоги.

Ламберт - злой гений Аркадия, «без стука» заходит в его сон, забирается в его подсознание, оставляя там грязные следы. И одновременно Ламберт - «двойник» подростка, темная сторона его души, его «Mr. Hyde», то худшее, что в нем есть, воплощение низкой части его натуры. Этот лукавый «двойник» соблазняет, искушает, туманит разум вином, женщинами. И это «второе я» часто оказывается сильнее - неслучайно он постоянно бил Аркадия в школе. Как отмечает Бердяев, «Достоевский проводит человека через бездны раздвоения - раздвоение основной мотив Достоевского <...>. [Бердяев, 1994б, с. 21]. «Раздвоение» говорит о присутствии в одном человеке двух противоположных начал, и Ламберт как раз такая противоположность, он «двойник» зеркальный, то есть не точная копия, а «обратное отражение». Определенная «зеркальность» проявляется и в истории двух «отцов» как у Аркадия, так и у Ламберта. «Второй отец» последнего - Аббат Риго, так называемый «святой отец» - отнюдь не святой. Он «сожительствует» с его матерью и в этом слышится что-то нечистое, пошлое, почти прямая противоположность даже Версилову, не говоря уже о Макаре, который «жил почтительно» и которого «поминали не иначе, как какого-нибудь святого и много претерпевшего» [Достоевский, 1972-1990, т. 13, с. 9]. У французского «отца» святости нет, духовного, глубокого нет. И это подчеркнуто его именем - Риго, особенно, если предположить, что оно заимствовано из романа Диккенса «Крошка Доррит» (Little Dorrit,1857), где персонаж по имени Риго Бландуа (Rigaud Blandois) оказывается злодеем, который, кстати, случайно получает компрометирующие бумаги, что, созвучно теме разоблачительного письма, вокруг которого завязывается интрига «Подростка». 
Ламберт - недалекий, низкий, с «подлыми чувствами» [Достоевский, 1972-1990, т. 13, с. 444] - обладает какой-то бешеной, демонической энергией. Джозеф Фрэнк образно называет Ламберта «Мефистофелем» Аркадия: “Arkady's old schoolfellow Lambert finally makes his appearance to serve as his Mephistopheles" [Frank, 2002, p. 187]. К этому можно добавить, что подобное сравнение косвенно звучит и в тексте Достоевского. Вспомним, как Тришатов увлечённо рассказывает Аркадию о своем тайном желании написать оперу на сюжет «Фауста», где «вместе с гимнами, почти совпадая с ними» [Достоевский, 1972-1990, т. 13, с. 352], слышится голос дьявола. В подтексте этого рассказа можно уловить намек на Мефистофеля Ламберта, от которого оба они в этот момент физически и одновременно метафизически отходят.

Фамилия этого «черного человека» невольно читается на саксонский манер, с ударением на первый слог, учитывая финальное «т» в ее написании. По-французски она должна произноситься Ламбер, с ударением на последний слог. Добавляя окончание «т» к французской фамилии, автор как бы соединяет возможные аллюзии - от Мефистофеля до Наполеона, которые вызывает этот почти мифический персонаж.

Достоевский пишет его портрет самыми разными средствами иногда напрямую показывая его вульгарные и жестокие поступки, а иногда - опосредованно, косвенно, как например, когда Ламберт заманивает Аркадия в ресторан, где скверно пахнет устрицами и сыром. Здесь возникает чувственная метафора чего-то неприятного, гнилого, отталкивающего, вызывающего брезгливость. И именно там Аркадий говорит Ламберту, у которого он когда-то был в «лакеях», что тот сам лакей, раб: «<...> у меня есть характер, побольше, чем у тебя, потому что ты в рабстве у первого встречного <... Ах, как скверно пахнет, сыром пахнет, сыром пахнет! Экая гадость!» [Достоевский, 1972-1990, т. 13, с. 355].

И там же Аркадий прямо заявляет, что Ламберт ему не друг. И в самом деле, в процессе движения романа подросток все больше отдаляется от этой своей неотступной тени. Ламберт совершенно не имел понятия о благородстве в отличие от Аркадия, который хоть и начинал крайне неблагородно на аукционе, все же имеет другие корни, другую кровную и духовную основу.

Аркадий постоянно и исступленно стремится бежать от Ламберта: «Я хочу прочь, я хочу выйти! Пустите меня, не держите меня...» 
[Достоевский, 1972-1990, т. 13, с. 278]. Он буквально жаждет вырваться, освободиться от власти своего двойника: «Он ужасно был уверен, что я не вырвусь, он обнимал и придерживал меня <...> [Достоевский, 1972-1990, т. 13, с. 361]. Эти глаголы «не вырвусь», «придерживал», опять же, одновременно и пластическая визуальная реальность, и символ попытки вырваться из цепких объятий искушения, порока, зависимости от денег, проникающих вглубь самого человека, блуждающего в лабиринтах между добром и злом. И на чисто физическом уровне, в котором, разумеется, заложен иносказательный смысл (как и везде в романе), Аркадий устремляется к «отцу» - Макару Ивановичу - буквально «кидается» к нему, «точно там был отвод всем наваждениям, спасение, якорь», на котором он сможет удержаться. [Достоевский, 1972-1990, т. 13, c. 297]. И Макар, которого, как начинает казаться Аркадию, он «давно ждал», говорит ему: «Все познай, чтобы, когда повстречаешь безбожника али озорника, чтоб ты мог перед ним ответить, а он чтоб тебя неистовыми словесами не забросал и мысли твои незрелые чтоб не смутил» [Достоевский, 1972-1990, т. 13, с. 288]. Здесь старцем как будто сформулировано напутствие Аркадию в отношении Ламберта и озвучены сомнения, клубящиеся в душе самого подростка. И хоть Аркадий знает, что не пойдет «странствовать с Макаром Ивановичем», но с этой минуты начинает понимать, что ищет «благообразия» [Достоевский, 1972-1990, т. 13, с. 291] и в эту сторону лежит его метафизический путь. Нельзя не согласиться с мыслью Т. Касаткиной, что «благодаря явлению Макара, “ротшильдова” идея Подростка в конце оборачивается “христовой” идеей. [Касаткина, 2004, с. 181-212].

В трансформации «идеи» Ламберт также играет не последнюю роль. Благодаря этому утрированно - почти до гротеска - злобному «спутнику» Аркадия, яснее очерчивается его внутренняя борьба с сами собой. Рядом с подростком «демон» - Ламберт и вокруг него бесконечные интриги, обман, подлость, но только борьба с ним и есть настоящий путь к познанию добра и зла. Автор «Потерянного рая» так писал на эту тему: «Добро и зло в этом мире, как мы знаем, произрастают вперемежку, и сознание добра настолько связано и сопряжено с познанием зла, так трудно порой отделить одно от другого из-за коварного их сходства <...>. Знание добра и зла, двух сросшихся близнецов, пришло в мир от одного надкушенного яблока. И, может быть, Адам обречен был познать добро и зло, или, что то же, познать 
добро через посредство зла. А если так, то каким образом может человек, не ведающий зла, сознательно предпочесть ему добро, избежать его?» [Мильтон, 1986, с. 31]. И в этом отношении завещание старца - «все познай» - по сути, отражает внутренний план самого романа, отражает какую-то важную его задачу. Идея эта одновременно почти гамлетовская - познать добро и зло, быть способным отличить одно от другого. И эта «гамлетовская тема» романа - путь к познанию истины - как представляется, также связана и с идеей «Князя», с идеей «благородства».

К концу романа все блуждания, спираль воспоминаний, движения духовного роста - все «возвращается <...> на круги своя» (Еккл. 1:6). Еще в самом начале (что на самом деле соответствует хронологическому завершению истории) Аркадий называет себя «отрезвившимся»: «Я пишу теперь как давно отрезвившийся человек и во многом уже почти как посторонний <...> [Достоевский, 1972-1990, т. 13, с. 22]. А к финалу романа он буквально попадает в комнату «для вытрезвления» - еще одна реализованная метафора. И там он погружается в раздумья: «В такую минуту решают судьбу свою, определяют воззрение и говорят себе раз на всю жизнь: “Вот где правда и вот куда идти, чтоб достать ее”. Да, те мгновения были светом души моей» [Достоевский, 1972-1990, т. 13, с. 438]. Так обозначено отрезвление, пробуждение и путь к свету.

Как уже говорилось, этот путь Аркадия витиеват, не прям и не скор. Он, как будто воплощает мысль Тришатова о том, что «мы искренне все хотим быть лучше, только все откладываем» [Достоевский, 1972-1990, т. 13, с. 352].

Как бы завершая круг внутреннего пути Аркадия, вновь, как и в самом начале, в финале романа звучит тот же навязчивый вопрос: «- Как фамилия? - крикнул мне кто-то. - Долгорукий, - проревел я. - Князь Долгорукий?» [Достоевский, 1972-1990, т. 13, с. 437]. На протяжении всего романа тональность и смысл этого вопроса приобретают все новые оттенки, и можно сказать, что к финалу само слово «князь», обращенное к Аркадию, все больше начинает соответствовать действительности, во всяком случае, в метафизическом плане.

В Аркадии «много разных качеств» и понятие о чести - не последнее из них. Он решает вызвать на дуэль обидчика своего отца, вступиться за дело чести. По дороге к «секунданту», он проходит мимо «Медного всадника». В подтексте вновь встает пушкинская тема, но теперь не «скупой рыцарь» а одноименная поэма, «Пиковая дама», 
дуэль Онегина, роковая дуэль самого Пушкина. Момент утреннего пути в поисках возможности восстановить справедливость, предстает, как опережающий свое время, совершенно модернистский «Поток сознания», где ощущения смешиваются с размышлениями в одновременном круговороте настоящего, прошлого и будущего: «В такое петербургское утро, гнилое, сырое и туманное, дикая мечта какого-нибудь пушкинского Германна из “Пиковой дамы” (колоссальное лицо, необычайный, совершенно петербургский тип - тип из петербургского периода!), мне кажется, должна еще более укрепиться» [Достоевский, 1972-1990, т. 13, с. 113]. Аркадий размышляет не столько о литературном герое, сколько через него о себе самом. Ведь «мечта» (о чем речь уже шла выше), о которой он на ходу вспоминает, имеет определенное сходство с наполеоновской «идеей» самого Аркадия, который, как и Германн, в какой-то момент, несмотря на всю расчетливость экономии, становится игроком. В этом многоплановом по возможным ассоциациям эпизоде на фоне монумента Петру встает и тема становления Аркадия в новую личность, желания стать «властелином своей судьбы», дерзко, с риском для жизни, заявить о себе. Его поток мыслей продолжается сюрреалистическим видением: «Мне сто раз, среди этого тумана, задавалась странная, но навязчивая греза: “А что, как разлетится этот туман и уйдет кверху, не уйдет ли с ним вместе и весь этот гнилой, склизлый город, подымется с туманом и исчезнет как дым, и останется прежнее финское болото, а посреди его, пожалуй, для красы, бронзовый всадник на жарко дышащем, загнанном коне?” [Достоевский, 1972-1990, т. 13, с. 113]. Образ болот и медного всадника - быть может, самый мощный, самый завораживающий во всем романе - многое говорит о подсознательном процессе в душе Аркадия. Здесь могут возникать разные толкования, в том числе и то, что это воображаемая картина какого-то очищения, возвращения к истокам и одновременно учитывая, что в подсознании подростка в этот момент присутствует и мысль о дуэли - визуализация его внутреннего, глубоко спрятанного вопроса: А что, если все исчезнет? Что, если я исчезну? Останется только что-то самое вечное - то, что поднимает человека ввысь...

В этом утреннем проходе Аркадия, на этом отрезке его жизненного пути, сконцентрировано бесконечно много смыслов. По крайней мере, явственно прослеживается еще один, имеющий не последнее отношение ко всему замыслу романа - намек и на гамлетовский путь. Прежде всего, в том отношении, что Аркадию, как 
и Гамлету, важно не столько убить обидчика, отомстить за отца, сколько понять самого себя, понять - почему люди такие, в конечном итоге - понять, где добро, а где зло. Ведь и вся книга подростка им для этого написана. Гамлетовская тема проходит тонкой нитью, на уровне глубокого подтекста, иногда поднимаясь на поверхность, и то лишь намекая на сложный внутренний ход мыслей и их ассоциативный ряд.

Вскоре после похода за секундантом Аркадий внезапно узнает, что Крафт, застрелился, и он как бы внутрь себя обращает свои вопросы: «Крафт? > ..> Вчера? На закате солнца? <...> Великодушный человек кончает самоубийством, Крафт застрелился - из-за идеи, из-за Гекубы... Впрочем, где вам знать про Гекубу!.. А тут - живи между ваших интриг, валандайся около вашей лжи, обманов, подкопов... Довольно!» [Достоевский, 1972-1990, т. 13, с. 128-129]. Слова Гамлета о Гекубе из второго акта трагедии «И все из-за чего? Из-за Гекубы! Что ему Гекуба, что он Гекубе, чтоб о ней рыдать?» [Шекспир,1960, т. 6, с. 66] относятся к способности актера пережить чужую боль, как свою. При встрече с Аркадием Крафт говорил о том, что «нравственных идей теперь совсем нет; вдруг ни одной не оказалось <...> [Достоевский, 1972-1990, т. 13, с. 54]. В этом Аркадию мог послышаться какой-то упрек самому себе, за безнравственность его собственной идеи. И теперь у него вырывается гамлетовское восклицание, которое можно интерпретировать примерно как такой внутренний текст: «Что ему моя идея и, вообще - что ему все эти идеи с их безнравственностью, а он - великодушный человек застрелился». Гекуба всплывает в подсознании подростка еще и от того, что совсем незадолго до известия о смерти Крафта он думал отомстить за отца, то есть Аркадий находился в позиции Гамлета и потому высказался словами Гамлета. Это совершенно джойсовское построение текста по принципу ассоциаций, возникающих в потоке сознания или подсознания. Это «Джойс» задолго до Джойса в отношении ассоциативных связей и техники «внутреннего монолога». К роману «Подросток» можно было бы отнести тот же эпиграф из «Метаморфоз» Овидия, который Джойс взял для своего «Портрета художника в юности» (A Portrait of the Artist as a Young Man, 1914) «И к ремеслу незнакомому дух устремил» [Джойс, 1993, с. 205]. Иными словами - Достоевский не только предсказывает в этом романе идеи своего следующего произведения, не только пророчески предсказывает будущее Европы и России, но и в стилистическом 
отношении он создает роман 20 века. И в этом, как представляется, состоит необыкновенная «увлекательность» и интрига романа. Она не столько в «разнообразии происшествий, пестроте действующих лиц <...>» [Мочульский, 1995. с. 475], сколько, вопреки им, в открытии новых возможностей слова.

Есть большое искушение вспомнить в этом контексте один из рассказов Рэя Брэдбери (Tomorrow's Child ,1948), где речь идет о ребенке будущего: «Мы дадим ему выучить монолог Гамлета, и он станет читать наизусть, и это прозвучит как отрывок из Джойса». [Брэдбери, 1987, с. 485]. Роман Достоевского как бы вошел в то будущее литературы, когда гамлетовская идея, уходя в область подсознания героя, выражается в тексте лишь намеком, а весь внутренний ход мыслей, их связки и сцепления читатель должен домыслить сам. Достоевский - прямой предтеча модернизма и эта тема не раз становилась предметом соответствующих исследований ${ }^{4}$ В романе «Подросток» мы лишний раз находим этому подтверждение.

В том же коротком высказывании Аркадия о Гекубе есть и другие созвучия с Гамлетом. В словах «А тут - живи между ваших интриг, валандайся около вашей лжи, обманов, подкопов... Довольно!» [Достоевский, 1972-1990, т. 16, с. 129] есть отголосок гамлетовской судьбы и его размышлений.

Героя Достоевского волнует поиск «правды жизни» [Достоевский, 1972-1990, т. 16, с. 63]. И это - истинно гамлетовский мотив, поскольку герою трагедии Шекспира даже после подробностей о гибели отца, важно не схватиться за меч с жаждой мести, а записать свои мысли и выводы по поводу услышанного: «Мои таблички, надо записать, / Что можно жить с улыбкой и с улыбкой / Быть подлецом <...> Шекспир, 1960, т. 6, с. 36]. Дневник подростка, его записи - тоже своеобразные «таблички», где он записывает то, что более всего волнует его воображение, память, совесть, и это его способ дойти до правды.

Представляется чрезвычайно важным, что «Заметки, планы и наброски» к роману Достоевский начинает с такой формулы: «Гамлет-христианан». [Достоевский, 1972-1990, т. 16, с. 5]. В лаконичном двуединстве соединяются образ - князя Мышкина, «князя-Христа», к которому подросток идет на протяжении романа, и образ Гамлета. И стать Гамлетом - это тоже, в определенном

4 См.: [Bradbury, 1990; Урнов, 1965; Хасиева, 2014]. 
смысле, что стать князем. «Князь Гамлет» - именно так на самом деле может звучать по-русски «принц Гамлет» и так называют его в переводе Сумарокова5. А вот князь Мышкин по-английски звучит также, как и «Prince Hamlet» - «Prince Myshkin» ${ }^{6}$, и так же в английских переводах обращаются к Долгорукому, когда интересуются, не князь ли он: «Prince Dolgoruky?»7 . И, конечно, не случайно тема князя - с одной стороны проходит лейтмотивом через весь роман, как что-то, чем Аркадий не является, а с другой - с самого начала его образ задумывается, как княжеский - «гамлетовский». Таким образом, название статьи «Уже не подросток, еще не князь» направлено на раскрытие той трансцендентальной цели, к которой автор ведет своего «подрастающего» героя с первой строки своих замыслов.

В финале подросток пишет: «Я кончил. Может быть, иному читателю захотелось бы узнать: куда ж это девалась моя «идея» и что такое та новая, начинающаяся для меня теперь жизнь, о которой я так загадочно возвещаю? Но эта новая жизнь, этот новый, открывающийся передо мною путь и есть моя же “идея”, та самая, что и прежде, но уже совершенно в ином виде, так что ее уже и узнать нельзя» [Достоевский, 1972-1990, т. 13, с. 451]. В начале романа, излагая свою идею «стать Ротшильдом», Аркадий записал: «Деньги, конечно, есть деспотическое могущество, но в то же время и высочайшее равенство, и в этом вся главная их сила. Деньги сравнивают все неравенства» [Достоевский, 1972-1990, т. 13, с. 74]. Постепенно, однако, в борьбе с «гнетом сильного, насмешкой гордеца, болью презренной любви» [Шекспир, 1960, т. 6, с. 71], идея «равенства» открывает другие возможности достижения, иными средствами «княжескими», благородными. В отличие от молодого князя Сокольского и уж тем более от Ламберта, он, в конце концов, выбирает не «лакейский путь, а княжеский».

Аркадий разрабатывает свою «идею» накопления до тонкостей, но долгим ходом всего романа приходит к другому ее содержанию и к другому способу ее достижения. Как запишет Достоевский «Идея наживы тускла. Солнце закатывается над Невой» [Достоевский, $1972-1990$, т. 16, с. 75]. Так по ходу романа ротшильдовская идея «тускнеет» на глазах и «“Подросток” завершается верой в новую жизнь, в новый идеал красоты» [Мочульский, 1995, с. 480].

\footnotetext{
5 См.: [Сумароков, 1748].

6 См.: [Dostoevsky, 1989].

7 См.: [Dostoevsky].
} 
По внутренней структуре это похоже на путь Раскольникова рациональность идеи, почти математический расчет ее достижения и постепенный приход к тому, что путь был избран неверный. Не сама идея плоха - помочь униженным и оскорбленным или стать независимым и равным, не «лакеем», а плохо то, как предполагалось этого достичь. Идея «свободы, равенства», в которой подростка сопровождал «кровожадный» француз, резонирует с наполеоновской идеей Раскольникова.

Раскольников приходит к истине через веру и любовь Сони. Подросток также приходит через веру и любовь Сони - своей матери и через веру и любовь «отца». «Само имя ее - София - таинственно значительно <...> образ <...> Софии Премудрости Божией» [Мочульский 1995. с. 481]. А оба отца его указали путь, один - христианина, другой - Гамлета. Умирая, Макар Долгорукий напоминает, что деньги - великое искушение и напутствует, прося прислушаться к словам Христа: «Поди и раздай свое богатство и стань всем слуга» [Достоевский, 1972-1990, т. 13, с. 311].

Версилов же, по сути, сформулировал и цель «идеи» Аркадия, и иной, «гамлетовский» способ ее достижения: «Пусть всякий подвиг чести, науки и доблести даст у нас право всякому примкнуть к верхнему разряду людей» [Достоевский, 1972-1990, т. 13, с. 173].

В максиме «Гамлет - христианин» смыкаются две линии романа, здесь встречаются Версилов и Макар Иванович, сближаются развилки пути Аркадия, и здесь сходятся «великий христианин» Диккенс [Достоевский, 1972-1990, т. 23, с. 37] и «пророк, посланный Богом, чтобы возвестить нам тайну о человеке, души человеческой» - Шекспир [Достоевский, 1972-1990, т. 11, с. 237]. Внутренне отвечая на гамлетовский вопрос «что благородней духом», Аркадий, в конце концов, избирает путь, который ведет его туда, «где живет Бог», и так готовится стать «князем», «Гамлетом - христианином».

«Подросток» - это не только перепутья главного героя, это и путь России в пока неясное будущее. Поэтому у романа открытый финал. В нем творится сложная проекция пути человека и истории. Символично, что умирающему страннику Аркадий рассказывает чтото о коммунизме, о котором и сам решительно еще ничего не знает, да и самое слово услыхал в первый раз. Версилов же говорит о будущем, как экономист, немного как мистер Домби, объясняющий суть денег, при этом предлагает почитать Апокалипсис. Предвосхищая «Великого инквизитора», отец Аркадия пророчески формулирует 
суть Женевских идей как «добродетель без Христа» [Достоевский, 1972-1990, т. 13, с. 173] и так далее.

Открытость финала романа придает особый смысл его названию. В нем как бы зашифрован вопрос: в кого вырастет человек? Так же, как заложен вопрос и в видении Медного всадника: «Куда ты скачешь гордый конь? И где опустишь ты копыта?» Иными словами: Куда устремляется Россия? Куда указывает рука истории?

Роман не исчерпывается сюжетом, порой излишне мелодраматичным, и его финал лишь условно намечен, не обличен в слова. «Подросток», как и «вся действительность не исчерпывается насущным, ибо огромною своею частию заключается в нем в виде еще подспудного невысказанного будущего Слова» [Достоевский, 1972-1990, т. 11, с. 237]. Будущее туманно, как туман над болотами, привидевшийся Аркадию. В записях августа 1874 года Достоевский повторяет: «Кончается вопросом Подростка: где правда в жизни? (которой он и ищет во все продолжение романа)»[Достоевский, 1972-1990, т. 16, с. 63]. Достоевский задает вопросы, а дальше тишина - "The rest is silence" [Shakespeare, 1982, p. 980].

Метафизика романа - его огромный гносеологический диапазон. И в этом пространстве пребывает мятущаяся душа и мысль его главного героя. Он вырастает, метафорически постепенно становясь князем - «князем Гамлетом» или «князем Мышкиным» или «просто князем» - и на этом обрывается «Подросток» - «одно из самых гениальных и не до конца оцененных творений Достоевского».

\section{Список литературы}

1. Бабук, 2012 - Бабук А.В. Художественный прием «мир глазами ребенка» в романе Ч. Диккенса «Большие надежды» и Ф.М. Достоевского «Подросток» // Вопросы русской литературы. 2012. №22 (79). C. $190-207$.

2. Баршт, 2003 - Баршт К. Герой Ф.М. Достоевского как подросток // «Педагогія» Ф.М. Достоевского. Сб. ст. Коломна, 2003, с. 9-20.

3. Бердяев, 1994а - Бердяев Н. Откровение о человеке в творчестве Достоевского // Философия творчества, культуры и искусства: в 2 т. М.: Искусство. 1994. Т. 2. С. 151-176.

4. Бердяев, $1994 б$ - Бердяев Н. Миросозерцание Достоевского // Философия творчества, культуры и искусства: в 2 т. М.: Искусство. 1994. Т. 2. С. 7-140.

5. Боборыкина, 2016 - Боборыкина Т.А. Достоевский и Уайльд: Ближе, чем кажется // Достоевский и мировая культура. Альманах. 2016. №34. С. 161-170. 
6. Боборыкина, 1998 - Боборыкина T.А. Художественный мир рождественских повестей Чарльза Диккенса. СПб.: Гиппократ, 1996. 138 с.

7. Брэдбери, 1987 - Брэдбери Р. И все-таки наш... // О скитаниях вечных и о Земле. М.: Правда, 1987. С. 476-493.

8. Гажева, 2018 - Гажева И. Свет вечерний в творчестве Ф.М. Достоевского // Sultanivski Chytannia. 2018. Вип.7. С. 225-241.

9. Даль, 2007 - Даль В.И. Толковый словарь живого великорусского языка. М.: ОЛМА медиагрупп, 2007. Т. 4.756 с.

10. Джойс, 1993 - Джойс Дж. Портрет художника в юности // Джойс Дж. Собр соч.: в 3 т. М.: Знаменитая книга, 1993. Т. 1. С. 205-445.

11. Диккенс, 1959 - Диккенс Ч. Рождественская песнь в прозе // Диккенс Ч. Собр. соч.: в 30 т., М.: Гос. изд-во. худож. лит-ры, 1959. Т. 12. С. 7-100.

12. Достоевский, 1972-1990 - Достоевский Ф.М. Полн. собр. соч.: в 30 т. Л.: Наука, 1972-1990.

13. Касаткина, 2003 - Касаткина Т.А. Два образа солнца в романе «Подросток» // Роман Ф.М. Достоевского «Подросток»: возможности прочтения. Коломна, 2003. С. 53-62.

14. Касаткина, 2004а - Касаткина Т.А. Два образа солнца в романе «Подросток» // О творящей природе слова. М.: ИМЛИ РАН, 2004. С. 438-446.

15. Касаткина, 20046 - Касаткина Т.А. Роман Ф.М. Достоевского «Подросток»: «Идея» героя и идея автора // Вопросы литературы. 2004. №1. С. 181-212.

16. Касаткина, 2019а - Касаткина Т.А. «Мальчик у Христа на елке» Ф.М. Достоевского: структура образа и эстетика действия // Достоевский и мировая культура. Филологический журнал. 2019. № 1. С. 16-40.

17. Касаткина, 2019б - Касаткина Т.А. «Живой мертвец» В.Ф. Одоевского как источник одного из базовых положений философии Достоевского и ряда структурных принципов его творчества // Литература и философия: От романтизма к XX веку. К 150-летию со дня смерти В.Ф. Одоевского / отв. ред. и сост. Е.А. Тахо-Годи. М.: Водолей, 2019. С. 344-353.

18. Криницын, 2010 - Криницын А.Б. Творчество Достоевского в контексте европейской литературы. 2010. URL: http://www.portal-slovo.ru/philology/42345.php (дата обращения: 23.08.2021).

19. Мильтон, 1986 - Мильтон Дж. Ареопагитика // Корабли мысли: Сборник. Английские и французские писатели о книге, чтении, библиофилах. Рассказы, памфлеты, эссе. М.: Книга, 1986. С. 22-37.

20. Мочульский, 1995 - Мочульский К.В. Достоевский. Жизнь и творчество // Гоголь. Соловьев. Достоевский. М.: Республика, 1995. С. 219-564.

21. Одоевский, 1959 - Одоевский В.Ф. Повести и рассказы / прим. Е.Ю. Хин. ГИХЛ, 1959. URL: https://ruslit.traumlibrary.net/book/odoevskiy-povesti/odoevskiypovesti.html (дата обращения: 23.08.2021).

22. Пушкин 1957-1958 - Пушкин А.С. Полн. собр. соч.: в 10 т. М.: Академия Наук СССР, 1957-1958.

23. Сумароков, 1748 - Сумароков. А.П. Гамлет. Трагедия. СПб.: Имп. Акад. наук, 1748. 69 с.

24. Тарасова, 2012 - Тарасова Н.А. Образ заходящего солнца в романе «Подросток»: Достоевский и Диккенс // Русская литература. 2012. №1. С. 124-132. 
25. Уайльд, 1993 - Уайльд О. «Униженные и оскорбленные» Достоевского // Избранные произведения: в 2 т. М.: Республика, 1993. Т. 2. С. 151-153.

26. Уайльд, 1912 - Уайльд О. Портрет Дориана Грея. Предисловие / пер. М. Ричардс // Уайлд О. Полн. собр. соч.: в 4 т. СПб.: Изд. Т-ва А.Ф. Маркс 1912. Т. 2. 3-212.

27. Урнов, 1965 - Урнов Д.М. Дж. Джойс и современный модернизм // Современные проблемы реализма и модернизм. М.: Наука, 1965. С. 309-345.

28. Хасиева, 2014 - Хасиева М. Психологизм Ф.М. Достоевского в культурной парадигме британского модернизма: дис. ... канд. филол. наук. М, 2014. 163 с.

29. Шекспир, 1960 - Шекспир У. Гамлет, принц датский // Шекспир У. Полн. собр. соч.: в 8 т. М.: Искусство, 1960. Т. 6. С. 5-157.

30. Dickens, 1984 - Dickens Ch. A Christmas Carol and Other Christmas Stories. NY (USA): Signet Classics, 1984, $223 \mathrm{p}$.

31. Dostoevsky, 1989 - Dostoevsky F.M. The Idiot / trans. by Julius Katzer. A Novel in Two Books. M.: Raduga Publishers, 1989.

32. Dostoevsky - Dostoevsky F.M. A Raw Youth / trans. by Constance Garnett. URL: http://gutenberg.net.au/ebooks01/0100161h.html (дата обращения: 23.08.2021).

33. Frank, 2002 - FrankJ. The Mantel of the Prophet, 1871-1881. Princeton: Princeton University Press, 2002. $784 \mathrm{p}$.

34. Bradbury, 1990 - Bradbury M. The Modern World: Ten Great Writers. London: The Pegasus Library. $1990.187 \mathrm{p}$.

35. Shakespeare, 1982 - Shakespeare W. The Tragedy of Hamlet, Prince of Denmark // The Complete Works. London; New York: Spring Books, 1982. Pp. 945-980.

\section{References}

1. Babuk, A.V. "Khudozhestvennyi priem 'mir glazami rebenka' v romane Ch. Dikkensa 'Bol'shie nadezhdy' i F.M. Dostoevskogo 'Podrostok” [“The Artistic Device of 'The World Through the Eyes of a Child' in Charles Dickens' Novel Great Expectations and Fyodor Dostoevsky's The Adolescent']. Voprosy russkoi literatury, no. 22 (79), 2012, pp. 190-207. (In Russ.)

2. Barsht, K. "Geroi F.M. Dostoevskogo kak podrostok" ["Fyodor Dostoevsky's Hero as an Adolescent"]. "Pedagogiia” F.M. Dostoevskogo. Sbornik statei [The "Pedagogy" of Fyodor Dostoevsky. Collected Articles], Kolomna, 2003, pp. 9-20. (In Russ.)

3. Berdiaev, N. "Otkrovenie o cheloveke v tvorchestve Dostoevskogo" ["The Revelation about Man in Dostoevsky's Works"]. Filosofiia tvorchestva, kul'tury i iskusstva: 2 tomakh [A Philosophy of Creativity, Culture, and Art: in 2 vols.], vol. 2, Moscow, Iskusstvo Publ., 1994, pp. 7-140. (In Russ.)

4. Berdiaev, N. "Mirosozertsanie Dostoevskogo" ["Dostoevsky's Worldview”]. Filosofiia tvorchestva, kul'tury $i$ iskusstva: $v 2$ tomakh [A Philosophy of Creativity, Culture and Art: in 2 vols.], vol. 2, Moscow, Iskusstvo Publ., 1994, pp. 7-140. (In Russ.)

5. Boborykina, T.A. "Dostoevskii i Uail'd: Blizhe, chem kazhetsia” ["Dostoevsky and Wilde: Closer Than It Looks”]. Dostoevskii i mirovaia kul'tura. Al'manakh, no. 34, 2016, pp. 161-170. (In Russ.)

6. Boborykina, T.A. Khudozhestvennyi mir rozhdestvenskikh povestei Charl'za Dikkensa [The Artistic World of Charles Dickens' Christmas Stories]. St. Petersburg, Gippokrat Publ., 1996. 138 p. (In Russ.) 
7. Bredberi, R. "I vse-taki nash...” [“Tomorrow's Child”]. O skitaniiakh vechnykh i o Zemle [Forever and the Earth], Moscow, Pravda Publ., 1987, pp. 476-493. (In Russ.)

8. Gazheva, I. "Svet vechernii v tvorchestve F.M. Dostoevskogo" ["The Evening Light in the Works of F.M. Dostoyevsky”]. Sultanivski Chytannia, issue 7, 2018, pp. 225-241. (In Russ.)

9. Dal', V.I. Tolkovyi slovar' zhivogo velikorusskogo iazyka [Explanatory Dictionary of the Living Great Russian Language], vol 4. Moscow, OLMA mediagroup Publ., 2007. 756 p. (In Russ.)

10. Dzhois, Dzh. "Portret khudozhnika v iunosti" ["A Portrait of the Artist as a Young Man”]. Sobranie sochinenii: 23 tomakh [Collected Works: in 3 vols.], vol. 1, Moscow, Znamenitaia kniga Publ., 1993, pp. 205-445. (In Russ.)

11. Dikkens, Ch. "Rozhdestvenskaia pesn' v proze" ["A Christmas Carol, in Prose”]. Sobranie sochinenii: $v 30$ tomakh [Collected Works: in 30 vols.], vol. 12, Moscow, State Literary Publishing House, 1959, pp. 7-100. (In Russ.)

12. Dostoevskii, F.M. Polnoe sobranie sochinenii: $v 30$ tomakh [Complete Works: in 30 vols]. Leningrad, Nauka Publ., 1972-1990. (In Russ.)

13. Kasatkina, T.A. "Dva obraza solntsa v romane 'Podrostok" ["Two Images of the Sun in the Novel The Adolescent"]. Roman F.M. Dostoevskogo "Podrostok": vozmozhnosti prochteniia [Dostoevsky's Novel The Adolescent: Possible Readings], Kolomna, 2003, pp. 53-62. (In Russ.)

14. Kasatkina, T.A. "Dva obraza solntsa v romane 'Podrostok" ["Two Images of the Sun in the Novel The Adolescent"]. O tvoriashchei prirode slova. Ontologichnost' slova v tvorchestve F.M. Dostoevskogo kak osnova "realizma v vyschem smysle" [On the Poietic Nature the Word. The Ontology of the Word in the Work of F.M. Dostoevsky as the Fundament of "Realism in a Higher Sense"], Moscow, IWL RAS Publ., 2004, pp. 438-446. (In Russ.)

15. Kasatkina, T.A. “Roman F.M. Dostoevskogo 'Podrostok': 'Ideia' geroia i ideia avtora” [“Dostoevsky's Novel The Adolescent. The 'Idea' of the Hero and the Idea of the Author"]. Voprosy literatury, no. 1, 2004, pp. 181-212. (In Russ.)

16. Kasatkina, T.A. “'Mal'chik u Khrista na elke' F.M. Dostoevskogo: struktura obraza i estetika deistviia” [“F.M. Dostoevsky’s Story ‘The Beggar Boy at Christ’s Christmas Tree’: The Image Structure and the Aesthetics of Action]. Dostoevskii i mirovaia kul'tura. Filologicheskii zhurnal, no. 1, 2019, pp. 16-40. (In Russ.) http://doi.org/10.22455/2619-0311-2019-1-16-40

17. Kasatkina, T.A. “'Zhivoi mertvets' V.F. Odoevskogo kak istochnik odnogo iz bazovykh polozhenii filosofii Dostoevskogo i riada strukturnyk printsipov ego tvorchestva” " "The Live Corpse by Vladimir Odoevsky as the Source for One of the Basic Tenets of Dostoevsky's Philosophy and Several Structural Principles of His Work"]. Literatura i filosofia: Ot romantisma $k$ XX veku. K 150-letiiu so dnia smerti V.F. Odoevskogo [Literature and Philosophy: From Romanticism to the $20^{\text {th }}$ Century. To the $150^{\text {th }}$ Anniversary of the Death of Vladimir Odoevsky], ex. ed. and comp. by E.A. Takho-Godi, Moscow, Vodolei, 2019, pp. 344-353. (In Russ.)

18. Krinitsyn, A.B. Tvorchestvo Dostoevskogo v kontekste evropeiskoi literatury [Dostoevsky's Wor$k s$ in the Context of European Literature]. 2010. http://www.portal-slovo.ru/philology/42345.php. Accessed 28 Aug. 2021. (In Russ.)

19. Mil'ton, Dzh. "Areopagitika” [“Areopagitica”]. Korably mysli: Sbornik. Angliiskie ifrantsuzskie pisateli o knige, chtenii, bibliografilakh. Rasskazy, pamflety, esse [Ships of Thought: A Collection. English and French Writers on Books, Reading, Bibliophiles. Stories, Pamphlets, Essays], Moscow, Kniga Publ., 1986, pp. 22-37. (In Russ.)

20. Mochul'skii, K.V. "Dostoevskii. Zhizn' i tvorchestvo" ["Dostoevsky. Life and Works”]. Gogol'. Solov'ev. Dostoevskii [Gogol. Solovyov. Dostoevsky], Moscow, Respublika Publ., 1995, pp. 219-564. (In Russ.) 
21. Odoevskii, V.F. Povesti i rasskazy [Tales and Stories]. Comm. by E.Iu. Khin. GIKHL Publ., 1959. https://ruslit.traumlibrary.net/book/odoevskiy-povesti/odoevskiypovesti.html Accessed 23 Aug. 2021. (In Russ.)

22. Pushkin, A.S. Polnoe sobranie sochinenii: $v 10$ tomakh [Complete Works: in 10 vols.]. Moscow, USSR Academy of Sciences Publ., 1957-1958. (In Russ.)

23. Sumarokov, A.P. Gamlet. Tragediia [Hamlet. A Tragedy]. St. Petersburg, Academy of Sciences Publ., 1748. 69 p. (In Russ.)

24. Tarasova, N.A. "Obraz zakhodiashchego solntsa v romane 'Podrostok’: Dostoevskii i Dikkens" ["The Image of the Setting Sun in The Adolescent. Dostoevsky and Dickens"]. Russkaia literatura, no. 1, 2012, pp. 124-132. (In Russ.)

25. Uaild, O. "Unizhennye i oskorblennye' Dostoevskogo" ["Dostoevsky's Humiliated and Insulted"]. Izbrannye proizvedeniia: $v 2$ tomakh [Selected Works: in 2 vols.], vol. 2, Moscow, Respublika Publ., pp. 151-153. (In Russ.)

26. Uaild, O. "Portret Doriana Greia. Predislovie" ["The Picture of Dorian Gray. Preface"]. Trans. by M. Richards. Polnoe sobranie sochinenii: $v 4$ tomakh [Complete Works: in 4 vols.], vol. 2, St. Petersburg, Izdatel'stvo T-va A.F. Marks, pp. 3-212. (In Russ.)

27. Urnov, D.M. "Dzhois i sovremennyi modernizm" [“Joyce and Contemporary Modernism”]. Sovremennye problemy realizma i modernism [Contemporary Problems of Realism and Modernism], Moscow, Nauka Publ., 1965, pp. 309-345. (In Russ.)

28. Khasieva, M. Psikhologism F.M. Dostoevskogo v kul'turnoi paradigme britanskogo modernizma [Fyodor Dostoevsky's Psychologism in the Cultural Paradigm of British Modernism. PhD Dissertation]. Moscow, 2014. 163 p. (In Russ.)

29. Shekspir, U. "Gamlet, prints datskii" ["Hamlet, Prince of Denmark"]. Polnoe sobranie sochinenii: $v 8$ tomakh [Complete Works: in 8 vols.], vol. 6, Moscow, Iskusstvo Publ., 1960, pp. 5-157. (In Russ.)

30. Dickens, Charles. A Christmas Carol and Other Christmas Stories. New York, Signet Classics, 1984. 223 p. (In English)

31. Dostoevsky, F.M. The Idiot. Trans. by Julius Katzer. A Novel in Two Books. Moscow, Raduga Publishers, 1989. (In Russ.)

32. Dostoevsky, F.M. A Raw Youth. Trans. by Constance Garnett. http://gutenberg.net.au/ebooks01/0100161h.html. Accessed 23 Aug. 2021. (In English)

33. Frank, Joseph. The Mantel of the Prophet, 1871-1881. Princeton, Princeton University Press, 2002. 784 p. (In English)

34. Bradbury, Malcom. The Modern World: Ten Great Writers. London, The Pegasus library, 1990. 187 p. (In English)

35. Shakespeare, William. "The Tragedy of Hamlet, Prince of Denmark". The Complete Works, London; New York, Spring Books, 1982, pp. 945-980. (In English)

Статья поступила в редакцию 29.08.2021

Одобрена после рецензирования 21.10.2021

Принята к публикации 25.10.2021

Дата публикации: 25.12.20211
The article was submitted 18 June 2021

Approved after reviewing 21 Sept. 2021

Accepted for publication 25 Sept. 2021

Date of publication: 25 Dec. 2021 